\title{
EFEKTIFITAS PENYEMBUHAN LUKA BAKAR SALEP EKSTRAK ETANOL DAUN SOYOGIK (Sauraia Bracteosa DC) PADA TIKUS PUTIH JANTAN GALUR WISTAR (Rattus Norvegicus)
}

\author{
Dea Puteri Utami Tumigolung ${ }^{1)}$, Max R. J. Runtuwene ${ }^{1)}$, Defny S. Wewengkang ${ }^{1)}$ \\ Program Studi Farmasi FMIPA UNSRAT Manado, 95115
}

\begin{abstract}
Soyogik leaves (Sauraia Bracteosa DC) contain flavonoids, phenolic, saponin and tannin. The contents in Soyogik Leaves is able to provide an effect to heal skin tissue damaged by burns. This study aims to formulate ethanol extract soyogik leaves ointment with concentration 20\%, $25 \%$ and $30 \%$ to be tested for it's effectiveness in healing burns. The method used is experimental laboratory. The wounds observation on the white rats back is done for 7 days by applying ointments 3 times a day. The results of the study showed that ethanol extract soyogik leaves with concentration 20\%, 25\%, and 30\% have a healing effect on burns characterized by the decreasing burns diameter of white rats and the ointment with the fastest healing effect is the ointments with a $30 \%$ concentration.
\end{abstract}

Keywords: Soyogik (Sauraia bracteosa DC), ointment, burns, white rats (Rattus norvegicus)

\begin{abstract}
ABSTRAK
Daun Soyogik (Sauraia Bracteosa DC) mengandung flavonoid, fenolik, saponin dan tanin. Kandungan yang terdapat dalam daun Soyogik mampu memberikan efek untuk menyembuhkan kulit yang mengalami kerusakan jaringan akibat luka bakar. Penelitian ini bertujuan untuk memformulasi sediaan salep ekstrak daun Soyogik dengan konsentrasi 20\%, 25\% dan 30\% untuk diuji efektifitasnya terhadap penyembuhan luka bakar. Metode yang digunakan ialah eksperimental laboratorium. Pengamatan luka bakar pada punggung tikus putih dilakukan selama 7 hari dengan mengoleskan salep sebanyak 3 kali sehari. Hasil penelitian menunjukan salep ekstrak etanol dun Soyogik dengan konsentrasi $20 \%, 25 \%$ dan $30 \%$ memiliki efek penyembuhan luka bakar diatandai dengan mengecilnya diameter luka bakar pada tikus dan efek penyembuhan yang paling cepat pada salep dengan konsentrasi $30 \%$.
\end{abstract}

Kata kunci: Soyogik (Sauraia bracteosa DC), salep, luka bakar, tikus putih (Rattus norvegicus) 


\section{PENDAHULUAN}

Luka bakar merupakan salah satu trauma yang sering terjadi dalam kehidupan seharihari. Luka bakar yang terjadi dapat disebabkan adanya kontak dengan sumber panas seperti api, air panas, bahan kimia, listrik dan radiasi sehingga mengalami kerusakan kulit. (Moenadjat, 2003).

Gangguan pada tubuh dan tingkat kematian yang disebabkan luka bakar ditentukan oleh luas dan dalamnya kulit yang terkena, status kesehatan sebelumya, serta usia pasien (Brunner \& Suddarth, 2002). Pasien dengan luka bakar luas (mayor), tubuhnya tidak akan mampu lagi untuk mengkompensasi sehingga timbul berbagai macam komplikasi yang memerlukan penanganan khusus (Effendi, 1999) seperti peningkatan permeabilitas pembuluh kapiler, kerusakan jaringan kulit dan gangguan serius pada paru-paru, ginjal, dan hati (Moenajat, 2003).

Masyarakat Indonesia masih sering menggunakan obat-obatan herbal sebagai media penyembuhan berbagai macam penyakit untuk mengurangi biaya. Soyogik (Sauraia bracteosa DC) adalah tanaman dalam Famili Actinidiaceae yang merupakan endemik Indonesia, dipercaya secara empiris oleh masyarakat Tombatu, Sulawesi Utara sebagai obat antikanker.

Beberapa studi mengenai daun soyogik telah dipublikasikan, aspek yang diteliti menyangkut analisis fitokimia, aktivitas antioksidan, uji toksisitas dan aktivitas perlindungan tabir surya. Menurut Kadji (2013) selain memliki aktivitas sebagai antioksidan, ekstrak etanol daun Soyogik memiliki kandungan fenolik, steroid, flavonoid, dan saponin.

\section{METODE PENELITIAN}

\section{Waktu dan Tempat Penelitian}

Penelitian ini dilaksanakan pada bulan Februari 2018 - September 2018 di Laboratorium Penelitian Farmasi dan Laboratorium Teknologi Farmasi Fakultas Matematika dan Ilmu Pengetahuan Alam Universitas Sam Ratulangi.

\section{Bentuk Penelitian}

Bentuk penelitian ini ialah eksperimental laboratorium.

\section{Alat}

Alat yang digunakan dalam penelitian ini yaitu masker, sarung tangan, jas lab, rotary evaporator, oven, alat-alat gelas, blender, timbangan analitik, lumpang, sudip, batang pengaduk, kertas saring, aluminium foil, $\mathrm{pH}$ meter, pencukur bulu, penggaris, plat besi, pot salep dan kertas label.

\section{Bahan}

Bahan-bahan yang digunakan yaitu daun soyogik, etanol 96\%, adeps lanae, vaselin album, bioplacenton, eter, kapas dan tikus putih.

\section{Pengambilan Sampel}

Sampel daun soyogik diambil di daerah sekitar gunung Soputan, Tombatu, Sulawesi Utara. Bagian yang digunakan adalah daun. Sampel yang diambil dibawa ke laboratorium untuk dibersihkan dari kotoran dan serangga dengan air mengalir. Sampel daun yang telah dibersihkan, disortasi degan cara mengamati keutuhan bentuk sampel daun yang akan diolah menjadi simplisia. 


\section{Penyiapan Serbuk}

Sampel daun soyogik dikeringkan dengan cara diangin-anginkan selama \pm 1 minggu. Setelah itu dimasukkan ke dalam oven pada suhu $50^{\circ} \mathrm{C}$ selama 1-2 hari hingga ketika diremas sampel daun menjadi hancur sebagai indikator kadar air dari sampel telah berkurang. Sampel yang telah dikeringkan kemudan dibuat serbuk dengan menggunakan blender khusus bahan kering.

\section{Ekstraksi}

Proses ekstraksi dilakukan dengan metode maserasi yaitu sebanyak 600 gram serbuk simplisia daun soyogik dipisahkan dalam dua wadah masing-masing 300 gram kemudian direndam dengan larutan etanol
96\% sebanyak $1500 \mathrm{~mL}$ dengan perbandingan 1:3. Proses ekstraksi dilanjutkan dengan melakukan remaserasi residu ditambahkan dengan pelarut etanol 96\% sebanyak $1000 \mathrm{~mL}$ dengan perbandingan 1:2. Ekstrak cair yang diperoleh kemudian diuapkan menggunakan rotary evaporator dengan suhu $40^{\circ} \mathrm{C}$ sampai diperoleh ekstrak etanol daun soyogik dan dipekatkan di dalam oven dengan suhu $40^{\circ} \mathrm{C}$ selama 3 hari.

\section{Formulasi Salep}

Pada penelitian ini akan dibuat sediaan salep ekstrak etanol daun Soyogik dengan konsentrasi, 20\%, 25\% dan 30\%. Dibuat formulasi $50 \mathrm{~g}$ salep dengan tiga variasi konsentrasi sebagai berikut:

Tabel 1. Perbandingan Jumlah Basis Salep dan Ekstrak Daun Soyogik

\begin{tabular}{cccc}
\hline & \multicolumn{3}{c}{ Konsentrasi } \\
\cline { 2 - 4 } Formulasi & $20 \%$ & $25 \%$ & $30 \%$ \\
\hline Basis Salep & $40 \mathrm{~g}$ & $37,5 \mathrm{~g}$ & $35 \mathrm{~g}$ \\
\hline Ekstrak Daun Soyogik & $10 \mathrm{~g}$ & $12,5 \mathrm{~g}$ & $15 \mathrm{~g}$ \\
\hline m.f.salep & $50 \mathrm{~g}$ & $50 \mathrm{~g}$ & $50 \mathrm{~g}$ \\
\hline
\end{tabular}

Pembuatan sediaan salep ekstrak etanol daun Soyogik dibuat formulasi sebanyak $50 \mathrm{~g}$ pada masing-masing konsentrasi yaitu 20\%, 25\% dan $30 \%$. Setelah masing-masing bahan ditimbang sesuai dengan perhitungan diatas, bahan dimasukan kedalam cawan porselin dileburkan diatas hot plate dengan suhu $60^{\circ} \mathrm{C}$ dan diaduk dengan kecepatan konstan.
Selanjutnya diangkat dan diaduk sampai terbentuk massa salep (Djumaati, 2017).

Sediaan Salep antibakteri selanjutnya dievaluasi untuk penjaminan mutu salep tersebut. Beberapa uji yang dilakukan pada salep yaitu uji organoleptik, uji homogenitas, uji $\mathrm{pH}$, dan uji daya sebar. 


\section{Penyiapan hewan uji}

Penelitian ini menggunakan 10 ekor tikus putih jantan dibagi menjadi 5 kelompok. Masing-masing kelompok terdiri atas 2 ekor tikus putih. Sebelum diberi perlakuan, tikus diaptasikan selama tujuh hari dan diberi makan setiap hari.

\section{Pembuatan luka bakar}

Tikus putih dianestesi dengan cara dimasukkan kedalam toples berisi kapas yang telah diberi eter, diamkan selama 3 menit sampai tikus teranestesi. Setelah itu, punggung tikus dicukur seluas $3 \mathrm{~cm} \times 3 \mathrm{~cm}$. Proses pembuatan luka bakar menggunakan plat besi yang telah dipanaskan dengan api (Pavlouskis et al, 2007). Luka bakar dibuat di daerah punggung tikus dekat vertebrae thoracalis dengan cara menempelkan plat

\section{HASIL DAN PEMBAHASAN}

\section{Ekstraksi}

Sampel basa daun Soyogik diperoleh sebanyak $800 \mathrm{~g}$, dikeringkan dan diblender menghasilkan serbuk simplisia daun Soyogik sebanyak 600 g selanjutnya diekstraksi dengan metode maserasi besi pada bagian punggung tikus selama 10 detik (Aulia, 2012).

\section{Pengujian efektfitas salep}

Tikus yang telah memiliki luka bakar dikelompokkan secara acak dalam 5 kelompok, masing-masing kelompok dengan 2 ekor tikus.

Kontrol positif : dioleskan bioplacenton

Kontrol negatif : dioleskan basis salep

Perlakuan I : konsesntrasi 20\%

Perlakuan II : konsentrasi 25\%

Perlakuan III: konsentrasi 30\%

\section{Analisis Data}

Data hasil penyembuhan luka bakar yang diperoleh secara keseluruhan dianalisis secara statistika menggunakan One Way ANOVA dan dilanjutkan dengan uji Tukey dan LSD.

menghasilkan ekstrak kental sebanyak $70,074 \mathrm{~g}$ dan diperoleh randemen sebanyak $11,68 \%$.

\section{Evaluasi Sediaan}

Uji Organoleptik

Tabel 3. Hasil Uji Organoleptik Salep Ekstrak Daun Soyogik

\begin{tabular}{|c|c|c|c|}
\hline Formulasi & Bentuk & Warna & $\mathrm{Bau}$ \\
\hline $\mathrm{KN}$ & Setengah padat & Putih kekuningan & Bau khas salep \\
\hline FI & Setengah padat & Hijau kehitaman & Bau khas ekstrak \\
\hline FII & Setengah padat & Hijau kehitaman & Bau khas ekstrak \\
\hline FIII & Setengah padat & Hijau kehitaman & Bau khas ekstrak \\
\hline
\end{tabular}




\section{Uji Homogenitas}

Tabel 4. Hasil Uji Homogenitas Salep Ekstrak Daun Soyogik

\begin{tabular}{cc}
\hline Formulasi & Homogenitas \\
\hline KN & Homogen \\
FI & Tidak homogen \\
FII & Tidak homogen \\
FIII & Tidak homogen \\
\hline
\end{tabular}

Uji pH

Tabel 5. Hasil Uji pH Salep Ekstrak Etanol Daun Soyogik

\begin{tabular}{cc}
\hline Formulasi & $\mathrm{pH}$ \\
\hline KN & 5 \\
FI & 5 \\
FII & 5 \\
FIII & 5 \\
\hline
\end{tabular}

Uji Daya Sebar

Tabel 6. Hasil Uji Daya Sebar Salep Ekstrak Daun Soyogik Formulasi

Daya Sebar $(\mathrm{cm})$

\begin{tabular}{cc}
\hline KN & 5,2 \\
FI & 6,3 \\
FII & 4,5 \\
FIII & 4 \\
\hline
\end{tabular}

\section{Pengujian Efektifitas Salep}

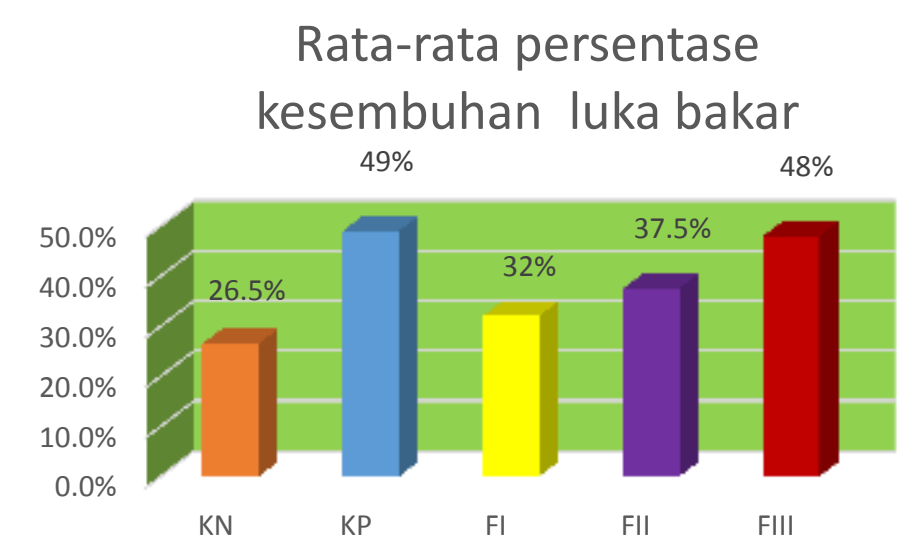

Gambar 1. Grafik Persentase Diameter Luka Bakar Tikus Putih

Keterangan:

$\mathrm{KN}$ : Formulasi Basis salep 
KP : Bioplacenton

FI : Formulasi sediaan salep ekstrak etanol daun soyogik konsentrasi $20 \%$

FII : Formulasi sediaan salep ekstrak etanol daun soyogik konsentrasi $25 \%$

FIII : Formulasi sediaan salep ekstrak etanol daun soyogik konsentrasi $30 \%$

\section{PEMBAHASAN}

Penelitian ini dilakukan dengan memformulasi sediaan salep luka bakar dengan menggunakan bahan aktif yang berasal dari daun Soyogik. Ekstraksi dilakukan untuk mencari komponen senyawa aktif yang berkhasiat. Ekstrak yang diperoleh dari proses ekstraksi dihitung rendamennya. Rendamen diperlukan untuk mengetahui dan membandingkan jumlah senyawa atau ekstrak yang dapat terambil oleh pelarut (Wijatmoko, 2008). Dalam penelitian ini, dilakukan perhitungan rendamen ekstrak karena ekstrak yang didapatkan akan dibuat sebagai bahan aktif sediaan farmasi. Dari segi farmasetik, untuk pembuatan sediaan farmasi perlu diketahui sifat fisiko-kimia dari seluruh komponen yang akan dicampurkan agar dihasilkan sediaan farmasi yang berkualitas (Wulandari, 2017).

Evaluasi sediaan salep meliputi uji organoleptik, homogenitas, $\mathrm{pH}$, dan daya sebar. Uji organoleptik pengamatan terhadap bentuk, warna dan bau salep. Hasil basis salep dan sediaan salep ekstrak etanol daun Soyogik dengan 3 konsentrasi tersebut memiliki bentuk setengah padat yang merupakan ciri khas dari salep. Menurut Anonim (1995) salep ialah sediaan setengah padat yang ditujukan untuk pemakaian topical pada kulit. Dari segi warna, basis salep menunjukkan warna khas dari salep yaitu putih kekuningan, karena adanya proses pencampuran dari kedua basis dimana vaselin album berwarna putih sedangkan adeps lanae berwarna kuning. Dan untuk hasil pengamatan sediaan ketiga konsentrasi salep ekstrak etanol daun Soyogik menunjukkan hasil yang sama yaitu berwarna hijau kehitaman karena dipengaruhi dengan ekstrak daun Soyogik. Dari segi bau, basis salep menunjukkan bau yang khas lemak dominan. Karena bahan yang digunakan merupakan bahan dari pemurniaan minyak bumi dan bulu domba. Sedangkan bau dari sediaan ekstrak etanol daun Soyogik pada ketiga konsentrasi menunjukkan hasil yang sama yaitu bau khas ekstrak yang telah menutupi bau dari basis salep. Uji homogenitas dilakukan dengan tujuan untuk melihat bahan-bahan dari sediaan salep tercampur dan tersebar menjadi homogen. Basis salep menunjukkan susunan yang homogen dan tidak menggumpal, hal ini berarti basis salep memenuhi persyaratan uji homogenitas. Untuk salep ekstrak etanol daun Soyogik FI, FII dan FIII menunjukkan susunan yang tidak homogen. Hasil penelitian tersebut belum memenuhi persyaratan uji homogenitas karena jenis zat aktif yang ditambahkan. Uji $\mathrm{pH}$ dimaksudkan untuk mengetahui sifat dari salep dalam pengunaannya pada kulit. Berdasarkan pengujian yang telah dilakukan menunjukkan bahwa basis salep dan salep ekstrak daun Soyogik FI, FII dan FIII memiliki $\mathrm{pH}$ 5. Hasil yang diperoleh dari pengujian tersebut telah sesuai dengan $\mathrm{pH}$ kulit yaitu 4,5-6,5 sehingga aman untuk 
digunakan, karena $\mathrm{pH}$ yang terlalu asam dapat mengiritasi kulit sedangkan $\mathrm{pH}$ yang terlalu basa dapat membuat kulit bersisik (Tranggono, 2007). Pengujian daya sebar untuk setiap sediaan salep dilakukan untuk melihat kemampuan sediaan menyebar pada kulit. Diameter daya sebar yang diperoleh untuk basis salep dan salep ekstrak daun Soyogik FI sudah memenuhi parameter yang ada dimana untuk sediaan semisolid adalah $5-7 \mathrm{~cm}$ (Garg et al, 2002). Sementara untuk salep ekstrak daun Soyogik pada konsesntrasi FII dan FIII tidak memenuhi parameter yang ada, hal ini disebabkan karena ekstrak yang tercampur tidak homogen, menggumpal dan terdapat butiran kecil sehingga daya sebar mengecil.

Luka bakar yang diamati dalam penelitian ini merupakan luka bakar derajat dua dangkal yang tampak dengan kerusakan jaringan kulit yang diikuti dengan adanya lepuhan yang pecah. Perlakuan terhadap kelompok kontrol negatif memberikan dampak penyembuhan paling lama, hal ini dikarenakan pada kontrol negatif hanya mengandung basis salep dan tidak terkandung zat aktif yang dapat membantu proses penyembuhan luka bakar. Pada pengujian kontrol positif bioplacenton memberikan efek penyembuhan yang paling cepat. Sedangkan FI memberikan efek sedikit lebih cepat dibandingkan kontrol negatif karena memiliki sedikit kandungan zat aktif yang membantu proses penyembuhan luka bakar dan kelompok FII memberikan efek yang lebih cepat dari kelompok FI Penyembuhan luka bakar pada kelompok FIII memiliki hasil yang hampir sama dengan kelompok kontrol positif dan memberikan efek yang stabil pada proses penyembuhan luka bakar dibandingkan perlakuan lainnya. Berdasarkan teori dan hasil yang diperoleh terdapat pengecilan zona nekrosis pada diameter luka bakar. Hal ini dikarenakan esktrak daun Soyogik mengandung senyawa flavonoid, steroid dan saponin yang dapat membantu proses penyembuhan luka bakar.

Selanjutnya dilakukan analisis statistic menggunakan aplikasi SPSS .Sebelum data dianalisis ditentukan terlebih dahulu hipotesis untuk pengambilan keputusan yaitu:

$\mathrm{HO}=$ Tidak terdapat perbedaan yang signifikan pada penyembuhan luka bakar di tiap perlakuan

$\mathrm{H} 1$ = Terdapat perbedaan yang signifikan pada penyembuhan luka bakar di tiap perlakuan

Taraf signifikan ( $\alpha=0,05$ atau 5\%)

Berdasarkan hasil dari uji One Way ANOVA diperoleh nilai signifikan > 0,05 sehingga dapat disimpulakan bahwa $\mathrm{H} 0$ diterima, yaitu tidak terdapat perbedaan yang signifikan pada penyembuhan luka bakar di tiap perlakuan secara keseluruhan.

\section{KESIMPULAN}

Dari hasil penelitian dapat disimpulkan bahwa :

1. Salep ekstrak etanol daun Soyogik FI, FII dan FIII memiliki efek penyembuhan luka bakar. Hasil uji pada tikus putih setelah dioleskan salep ekstrak daun Soyogik terjadi pengecilan diameter luka pada zona nekriosis. Penyembuhan luka bakar yang paling cepat terdapat pada salep ekstrak etanol daun Soyogik FIII dengan konsentrasi $30 \%$. 
2. Salep ekstrak etanol daun Soyogik belum memenuhi parameter sediaan salep pada uji daya sebar dan homogenitas.

\section{SARAN}

1. Perlu dilakukan penelitian lebih lanjut mengenai evaluasi sediaan salep ekstrak etanol daun soyogik pada konsentrasi $5 \%$, $10 \%$ dan $15 \%$.

2. Perlu dilakukan penelitian mengenai kandungan kimia dari bagian soyogik yang lain seperi bunga, buah dan batang pohon soyogik.

\section{DAFTAR PUSTAKA}

Anonim. 1995. Farmakope Indonesia. Edisi Keempat. Jakarta: Departemen Kesehatan RI.

Aulia, A.F. 2014. Pengaruh Pemberian Salep Ekstrak Daun Binahong (Anredera cordifolia (Tenore) Steenis) terhadap Pembentukan Jaringan Granulasi pada Luka Bakar Tikus Sprague dawley. [Skripsi]. Jakarta: Fakultas Kedokteran dan Ilmu Kesehatan UIN Syarif Hidayatullah.

Brunner, L.S. dan D.S. Suddarth. 2002. Buku Ajar Keperawatan Medikal Bedah. EGC. Penerbit Buku Kedokteran, Jakarta.

Djumaati, F. 2017. Formulasi Sediaan Salep Ekstrak Etanol Daun Kelor (Moringa oleifera Lamk.) dan Uji Aktivitas Antibakterinya terhadap Bakter Staphylococcus aureus. [Skripsi]. Manado: Fakultas Matematika dan Ilmu Pengtahuan Alam Universitas Sam Ratulangi.
Effendi. 1999. Perawatan Pasien Luka Bakar. Jakarta: Penerbit Buku Kedokteran EGC Press.

Garg, A.D., Aggarwal, Garg S., Sigla, A.K. 2002. Spreading Of Semisolid Formulation: An Update. Pharmaceutical Tecnology. Septtember 2002 : 84-102.

Kadji, H. M. Uji Fitokimia dan Aktivitas Antioksidan dan Ekstrak Etanol Daun Soyogik (Sauraia bracteosa DC). [skripsi]. Manado: Fakultas Matematika dan Ilmu Pengtahuan Alam Universitas Sam Ratulangi .

Moenajat, Y. 2003. Luka Bakar dan Penanganannya Edisi Kedua. Jakarta: Balai Penerbit FKUI.

Tranggono, R.I., Latifah, F. 2007. Buku Pegangan Ilmu Pengetahuan kosmetik. PT. Gramedia, Jakarta.

Wijatmoko, Agus., 2008. Isolasi dan Uji Genotoksisitas Inhibitor Topoisomerase I dari Daun Ipomoea pes-caprae. [Tesis] Sekolah Pascasarjana IPB, Bogor

Wulandari, S.S. 2017. Aktivitas Perlindungan Tabir Surya secara In Vitro dan In Vivo dari Krim Ekstrak Etanol Daun Soyogik (Sauraica bracteosa DC). [Skripsi]. Manado: Fakultas Matematika dan Ilmu Pengtahuan Alam Universitas Sam Ratulangi. 